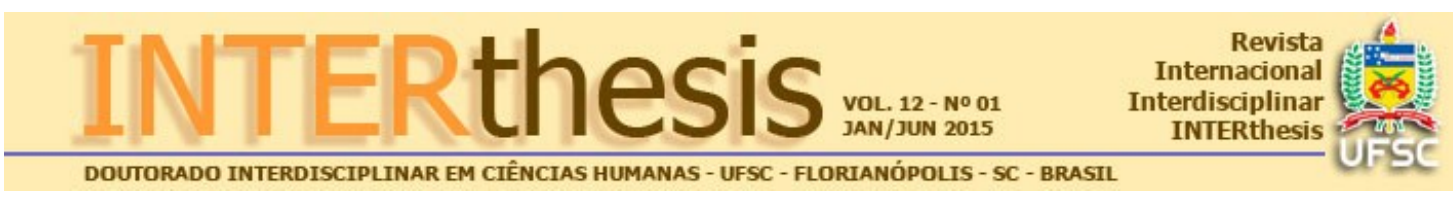

\title{
DA CITAÇÃO DO TRÁGICO. NOTAS SOBRE TRADIÇÃO E INTRANSMISSIBILIDADE
}

Vanessa Cunha Prado D'Afonseca ${ }^{1}$

\section{Resumo:}

Se não há dúvida de que a tradição do teatro antigo nos legou algo de sua experiência, a ponto de nomearmos tragédias algumas obras de Shakespeare e Goethe e entendermos como trágicos também alguns momentos do cinema de Pasolini e Bergman, como é possível falar em morte da tragédia, em rompimento da mola trágica? Ao mesmo tempo, como é possível que um mundo sem deuses, com uma compreensão da ação que a concebe guiada por uma faculdade interior que nem existia para o grego do século V A.C., a vontade, comporte ainda lugar para que, nele, algo se denomine tragédia? A solução a essas perguntas depende da compreensão de história que orienta o pesquisador, pensador ou colecionador que as formula. Tal diferença ficará muito clara se tomarmos como opostos o conceito de transistoricidade - característico da resposta de Vernant e Naquet a essas mesmas perguntas - e a noção de intransmissibilidade, indicada no uso das citações por Hannah Arendt.

Palavras-chave: Tragédia. Instransmissibilidade. Transistoricidade. Hannah Arendt. Vernant-Naquet.

A tragédia, nota Aristóteles, é a imitação de uma ação, mimesis práxeos.“[...] Pílades, que fazer?" Exclama Orestes nas Coéforas e Pelasgo no início de As Suplicantes verifica: "Não sei o que fazer; a angústia toma conta de meu coração; devo ou não agir?". O rei, entretanto, acrescenta imediatamente uma fórmula que, ligada à precedente, sublinha a polaridade da ação trágica: "Agir ou não agir, [...], e tentar o destino?" Tentar o destino: nos Trágicos, a ação humana não tem força o bastante para deixar de lado o poder dos deuses, nem autonomia bastante para conceber-se plenamente fora deles. [...] de um lado, é deliberar consigo mesmo, pesar o pró e o contra, prever o melhor possível a ordem dos meios e dos fins; de outro, é [...] entrar num jogo de forças sobrenaturais sobre as quais não sabemos se, colaborando conosco, preparam nosso sucesso ou nossa perda. Até no homem mais previdente, a ação mais refletida conserva o caráter de um ousado apelo aos deuses a respeito do qual só pela resposta que é dada e, no mais das vezes, por experiência própria, se conhecerá sua importância e sentido preciso. É no final do drama que os atos assumem sua verdadeira significação e os agentes, através daquilo que realizaram sem saber, revelam sua verdadeira face. Enquanto tudo não se consumou, ainda os casos humanos continuam a ser enigmas que são tanto mais obscuros, quanto mais os atores se julgam seguros daquilo que fazem e são. (Vernant e Vidal-Naquet, 2005).

\footnotetext{
${ }^{1}$ Mestre em Educação pela Universidade Federal de Santa Catarina. Pesquisadora do Núcleo de Estudos e Pesquisas Educação e Sociedade Contemporânea na Universidade Federal de Santa Catarina, Florianópolis, SC, Brasil. E-mail: vanessadafonseca@hotmail.com
}

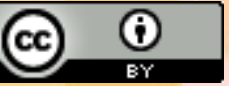


Os homens sempre souberam que aquele que age nunca sabe exatamente o que está fazendo; que sempre vem a ser "culpado" de consequências que jamais desejou ou previu; que, por mais desastrosas e imprevistas que sejam as consequências de seus atos, jamais poderá desfazê-lo; que o processo por ele iniciado jamais termina inequivocamente num único ato ou evento, e que seu verdadeiro significado jamais se revela ao ator, mas somente à visão retrospectiva do historiador, que não participa da ação. Tudo isso é motivo suficiente para que o homem se afaste, desesperado, da esfera dos negócios humanos e veja com desdém a capacidade humana de liberdade que, criando uma teia de relações entre os homens, parece enredar de tal modo o seu criador que este lembra mais uma vítima ou um paciente que o autor e agente do que fez. Em outras palavras, em nenhum outro campo - nem no labor, sujeito às necessidades da vida, nem na fabricação, dependente das matérias-primas que lhe são dadas - o homem parece ter menos liberdade que no gozo daquelas capacidades cuja essência é precisamente a liberdade, e naquela esfera que deve sua existência única e exclusivamente ao homem. (Hannah Arendt, 2001a).

I

Tipicamente trágica é a ambiguidade insolúvel entre o excesso e a continência, entre hybris e ethos, entre maldição e caráter na obra clássica de Jean-Pierre Vernant e Vidal-Naquet, Mito e Tragédia na Grécia Antiga (2005). Ambiguidade reconhecível em sua insolubilidade também na obra arendtiana. Excesso e continência, por exemplo, manifestos na relação complexa entre o caráter malogrado da ação, apresentado por Arendt n'A Condição Humana - em que a ação é toda transbordamento: imprevisível, ilimitada, irreversível (2001a, p.188-255) -, e a condição de nosso espírito só vir a saber da ação na continência do causal.

Desde que, para Arendt, só é possível saber da ação ao desta ser feita uma história (2001a, p. 204-5), causalidade e liberdade articulam-se tragicamente em um agir que escapa ao controle instrumental de si mesmo e um pensamento sobre o agir em que a própria narração da liberdade, ao fazer da ação uma história, torna-a necessariamente ambígua pela tonalidade de causalidade que a coerência do enredo Ihe impõe.

Não nos contentemos, contudo, com as semelhanças descritivas. Em primeiro lugar, é preciso notar que, em Arendt, se é possível falar em tragicidade, esta precisa conceber-se secularizada, com a ação tornando-se dilemática não mais na tensão de um atravessamento dos deuses no agir dos homens, mas por algo que lhe é inerente. $\mathrm{Na}$ autora, o que faz da liberdade um enigma é a pluralidade, a condição de que a ação incide e adquire sentido em uma teia de relações conformada nos atos e palavras de outros homens, tornando impossível decidir de cada ação se esta é 
"agência" ou então "paciência" (2001a, p. 203). Ação e reação aparecem tão indiscrimináveis que, mais uma vez, é a causalidade a aparecer, em detrimento da liberdade, como o único fenômeno realmente verificável.

Por outro lado, encontra-se em Vernant e Naquet uma teorização interessada em uma subjetivação política calcada nos artifícios dramáticos, temáticos e técnicos da encenação trágica, e, em Hannah Arendt, pelos dilemas espirituais diante da ação e da ação diante do pensar, do querer e do julgar, mas que, nos três autores, articula ao trágico questões que concernem ao tempo tanto quanto à história. Desde aí a possibilidade de diálogo para além do simples eco entre ação e tragédia, mas desde aí também a conformação de um diálogo que é explicitação de um limite. Para além do descritivo está a crítica histórica. Em outros termos, é indo até a borda de uma concordância possível entre Arendt e os dois helenistas franceses que se vislumbra o abismo interposto entre uma recepção da herança trágica pelo viés do conceito de transistoricidade em tensão com o de historicidade, forjado por Vernant e Naquet, e a crítica arendtiana à impossibilidade de acessarmos a Grécia antiga pela partilha de uma herança, explicitada na teorização de uma ruptura com a tradição e a consequente quebra entre o passado e futuro.

Tomemos, inicialmente, Arendt. De que maneira a autora se refere à tragédia? Um primeiro ponto a notar é que são poucas as referências feitas por ela diretamente ao trágico. Foram apenas cinco as que pude encontrar: uma, no $A$ Condição Humana, em que Arendt rememora a descrição aristotélica da representação trágica como "imitação da ação" (2001a, p. 200); outra, encontrada no Entre o Passado e o Futuro, em que a autora retoma o lamento de um Hamlet confrontado com o comando de vingança de seu pai - "O tempo está fora dos gonzos", diz Hamlet, "Oh! sorte maldita que nos fez nascer para restabelecer o seu curso" (2001b, p. 242)2; há o Édipo com a doxa destruída no "Filosofia e Política" (2002,

\footnotetext{
${ }^{2}$ É conhecido o debate em torno da consideração de Hamlet como trágico ou anti-trágico. Tome-se, por exemplo, a opinião de Susan Sontag em "A morte da Tragédia", sustentada em diálogo com a tese de Lionel Abel em Metatheatre: A New View of Dramatic Form: "a maioria das peças de Shakespeare, chamadas por seu autor e por todos, a partir de então, tragédias, no sentido estrito não são absolutamente tragédias. [...] As principais peças de Shakespeare são peças sobre a consciência de si, sobre personagens que não representam mas dramatizam a si mesmos num papel". (SONTAG: 1987, p.159). Em nosso contexto, porém, a decisão por trazer Hamlet na companhia dos heróis trágicos descende de um deslocamento da questão. Interessa-nos menos o
}

R. Inter. Interdisc. INTERthesis, Florianópolis, v.12, n.1, p.321-336, Jan-Jun. 2015 
p. 105); uma Antígona que serve como metáfora à experiência do pensar, em $A$ Vida do Espírito (2010, p.196) e, finalmente, é um Édipo já envelhecido, o Édipo preparado para a morte em Colono, quem lamenta as condições humanas da existência. $\mathrm{Na}$ última página de Sobre a Revolução, a sentença que Sófocles faz passar pela boca edipiana parece a Arendt assustadora: "É cem vezes melhor não ter nascido", afirma Édipo, "mas se temos de ver a luz do dia, o menor mal será ainda voltar ao lugar de onde viemos tão depressa quanto possível". Sentença que Arendt responde pelas palavras de Teseu - fundador de Atenas - "era a polis, o espaço das ações livres e das palavras vivas dos homens, aquilo que poderia dotar a vida de esplendor" (2001c, p. 246).

Entretanto, e a despeito de serem poucas, seria enganoso tomar o caráter fragmentário dessas referências ao trágico sob o signo da escassez. Se já os lugares em que aparecem são por demais significativos, suas presenças como citações parecem conter um convite da autora para que o leitor a acompanhe em seu trabalho de acesso ao passado no pensamento de um presente que responde ao ainda não do futuro. A hipótese aqui é que citar o passado tenha para Arendt, em semelhança com Walter Benjamin, a função de comunicar ao leitor o caráter intransmissível de algo que, em algum momento no tempo, já se apresentou; quer seja a intransmissibilidade decorrente do esfacelamento da tradição, quer seja expressão de um soterramento que deixou fossilizados, mas sem nomes, os germes do que poderia ter sido a origem de uma outra história. Se for assim, ao indicar o intransmissível ao mesmo tempo em que evoca o passado, o ato de citar delinearia uma forma específica de lidar com o tempo, com a tragédia e com a história.

Tanto em Arendt como em Benjamin, a citação, quando sinaliza o esfacelamento da tradição, remete a descontextualização e a recorte. Aquele que cita, diz Arendt sobre Benjamin e indiretamente sobre si mesma, como o colecionador, ao mesmo tempo em que preserva, "destrói o contexto onde seu objeto outrora apenas fez parte de uma entidade viva maior, e como somente o único genuíno interessa a ele, é preciso purificar o objeto escolhido de tudo o que há de típico" (2001, p.197). Se hoje, lembra a autora, o colecionador de citações do passado prescinde de destruir, é porque "a ruptura da tradição que ocorreu no início

reconhecimento do trágico no teatro elisabetano do que a questão sobre a decisão de Shakespeare em sustentar o nome tragédia em um contexto diverso ao da polis.

R. Inter. Interdisc. INTERthesis, Florianópolis, v.12, n.1, p.321-336, Jan-Jun. 2015 
deste século já o liberara dessa tarefa de destruição, e só lhe foi preciso, por assim dizer, inclinar-se para selecionar seus preciosos fragmentos entre o monte de destroços" (2001, p.197).

Diante do fato de uma já dada destruição, porém, aquele que cita deve ter cuidado.

\begin{abstract}
[...] a possível vantagem de nossa situação, subseqüente à morte da metafísica e da filosofia, apresenta duas faces. Ela nos permitiria olhar o passado com novos olhos, sem o fardo e a orientação de quaisquer tradições, e, assim, dispor de enorme riqueza de experiências brutas, sem estarmos limitados por quaisquer prescrições sobre a maneira de lidar com esses tesouros. "Notre héritage n'est precede d'aucun testament" ("Nossa herança não foi precedida por nenhum testamento"). A vantagem seria ainda maior, não fosse ela acompanhada de modo quase inevitável por uma crescente dificuldade em nos movermos em qualquer nível no domínio do invisível; ou, para falar de outro modo, não tivesse sido ela acompanhada pelo descrédito em que caiu tudo o que não é visível, tangível, palpável, de tal forma que nos encontramos em perigo de perder o próprio passado junto com as tradições. (ARENDT:2010, p. 27).
\end{abstract}

Após a ruptura, é como destroço que a tradição ainda se faz presente, soterrando a experiência daquele fóssil-tesouro que, até então, ela nomeava de forma coerente à sua discursividade. Daí Arendt definir como de desmontagem seu procedimento de reencontro com a política, com a ação e com o pensar nos rasgos do tecido discursivo da tradição metafísica. Um discurso que ela nomeia como falacioso, porém não arbitrário e que, em sua não arbitrariedade, torna-se testemunho do significado do pensar. Cuidado de Arendt não apenas com o passado soterrado, mas também com a tradição.

Já que me detive nas "falácias" metafísicas, que, como vimos, contêm indicações importantes sobre essa atividade curiosa e fora de ordem chamada pensamento, [...] juntei-me claramente às fileiras daqueles que, já há algum tempo, vêm tentando desmontar a metafísica e a filosofia, com todas as suas categorias, do modo como a conhecemos, desde o seu começo, na Grécia, até hoje. Tal desmontagem só é possível se aceitarmos que o fio da tradição está rompido e que não podemos reatá-lo. Historicamente falando, o que de fato se partiu foi a trindade romana que por milhares de anos uniu religião, autoridade e tradição. A perda dessa trindade não destrói o passado, e o processo de desmontagem em si mesmo, não é destrutivo; ele apenas tira conclusões a respeito de uma perda que é um fato [...] O que se perdeu foi a continuidade do passado, tal como ela parecia passar de geração em geração, desenvolvendose no processo de sua própria consistência. [...] Aquilo com o que se fica é ainda o passado, mas um passado fragmentado, que perdeu sua certeza de julgamento. Para ser breve, vou citar umas poucas linhas que falam melhor e de modo mais denso que eu poderia fazê-lo:

R. Inter. Interdisc. INTERthesis, Florianópolis, v.12, n.1, p.321-336, Jan-Jun. 2015 


\begin{abstract}
A cinco braças jaz teu pai,
De seus ossos se fez coral.

Aquelas pérolas foram seus olhos,

Nada dele desaparece

Mas sofre uma transformação marinha

Em algo rico e estranho.
\end{abstract}

A tempestade, Ato I Cena $2^{3}$

\begin{abstract}
Lidei aqui com esses fragmentos do passado após a transformação marinha por que passaram. Devemos à trilha intemporal que o pensamento vai pavimentando no mundo do espaço e do tempo, o fato de podermos usar esses fragmentos. (ARENDT: 2010, p. 234-235).
\end{abstract}

Neste contexto, não devem ser tomadas como meras ilustrações as falas de Aristóteles, Édipo e Hamlet no texto arendtiano. Remetendo ao soterramento e à desmontagem as citações podem acenar ao leitor num convite ao pensamento metalinguístico sobre as relações que a autora estabelece entre a poesia e a metáfora, o tempo e a história. Aí a dificuldade reside em ser preciso estar atento ao diálogo com o trágico ali onde ele está ausente, mas quem marca presença é o comentário sobre o soterramento de sua experiência, pois este só aparece ao leitor quando considerado à luz da factualidade de um acontecimento: ter tido a tragédia, já na Grécia antiga, encontrado o seu fim como uma experiência social, subjetiva e estética reconhecível por seu caráter inédito e por sua singularidade. Como afirmam Vernant e Naquet (2005, p.7), foi preciso menos de um século, para que a "mola trágica" se rompesse, para que a tragédia se apagasse diante do triunfo de uma nova instituição: a filosofia. É, pois, a memória desse apagamento, pré-requisito para encontrá-lo implícito também em Arendt e para acessar o nível metalinguístico da citação.

Mas o que teria provocado o rompimento da mola trágica? Para Naquet e Vernant, por um lado, as ambiguidades diversas que caracterizam o gênero trágico afrontariam um a um os fundamentos do que a filosofia passava a chamar pelo nome verdade. A esses autores, para entender o repúdio ao trágico na filosofia de Platão, por exemplo, seria necessário perceber que a tragédia, pelo simples fato de representar '"uma ação e a vida', é contrária a uma lógica filosófica para quem, dentre duas proposições contraditórias, se uma é verdadeira, a outra necessariamente é falsa". Na tragédia, não haveria, para esses autores, "um corte tão nítido entre o verdadeiro e o falso". Próxima à lógica dos retores, a ela

${ }^{3}$ Trecho citado em inglês pela autora e traduzido, em nota de rodapé, pelo tradutor.

R. Inter. Interdisc. INTERthesis, Florianópolis, v.12, n.1, p.321-336, Jan-Jun. 2015 
interessaria "discursos duplos que, em sua oposição, lutam entre si sem se destruir mutuamente" (2005, p.7).

Por outro lado, no contexto sócio cultural dos concursos trágicos e no contexto psicológico da constituição de um sujeito estético para o teatro e para a política, Naquet e Vernant encontram, na relação temporal dos autores das tragédias com o passado mítico, um ponto de passagem e de apagamento de um dos núcleos fundamentais da constituição da ambiguidade trágica. Vale dizer, o caráter de fato religioso e não apenas mimético da relação da tragédia com o passado heróico. Para eles, a tensão entre religião e política seria o ponto de concentração da energia da mola trágica, uma vez que a origem da tragédia estaria enraizada na experiência espiritual que o aparecimento da pólis fez constituir e colidir com o universo espiritual heróico e mítico anterior ao advento da cidade. De um lado, um repertório de lendas heróicas do qual o poeta se serve sem inventar as personagens, do outro um trabalho poético de tragicização, que não é para esses dois helenistas franceses mais do que o julgamento do mito, com suas lendas e seus heróis, mas que é um julgamento absolutamente ambíguo porque ainda próximo demais de um direito atravessado pela justiça dos deuses e pela ameaça do retorno da recém superada tirania.

Contraindo, portanto, os diversos anéis da mola trágica estariam os mitos carregados por conteúdos transgressivos tais quais o incesto, o parricídio, o matricídio e o infanticídio, conteúdos esses anteriores ao trágico e que só se tornariam tragédia nas mãos do poeta que passa a olhá-los com os novos olhos de cidadão, um olhar de julgamento que começa a se constituir com os novos adventos do direito e da pólis. O herói, que na tradição épica é sempre um chefe ou um rei, um homem nobre e membro "das grandes famílias reais do passado sobre as quais pesam as poluções e maldições ancestrais", homem atravessado por uma potência religiosa, por "um dáimon que age através dele" (Vernant; Naquet, 2005, p.13-15), precisará encontrar-se dilacerado, fazendo opor ao dáimon um êthos, à maldição um caráter, para que possa ser dito trágico.

Mas notemos, além disso, que em Vernant e Naquet não é pouco o que está contido nessa oposição herói-cidadão, êthos-dáimon. Em um primeiro nível, o julgamento da lenda é também julgamento da cidade recém fundada, pois se o contraste faz distanciar a democracia da tirania, esse outro de um tempo longínquo 
mas ainda próximo torna problemáticos os fundamentos ainda não fixados da pólis. É nesse sentido que os autores afirmam que, com a tragédia, a cidade se faz teatro e é um sujeito trágico-político o que se constitui. Em um segundo nível, a ligação ainda religiosa, mas agora ambígua, com as lendas heróicas inventa a abertura para uma dimensão temporal própria de uma nova forma de conceber o pensamento sobre a ação. A consciência da imitação constituída em concomitância ao próprio advento trágico rompe com a função de desvelamento da realidade que a poesia ainda tinha na tradição da epopéia, onde o poeta era como um profeta inspirado pelas musas, uma espécie de adivinho que revelava "o que é, foi e será" (2005, p. 216). Com isso, a imitação da ação proporá ao espectador um espetáculo em que o problema também é a temporalidade. O herói que não se apresenta, mas se representa por meio do ator no instante do espetáculo instaura a brecha para um jogo de recordação segura do passado, mas que é problematização insistente do presente. No palco, nenhum dos tempos - presente, passado e futuro - se oculta, mas, juntos, compõem, no aí da cena, um jogo de presenças e ausências que fará com que a ação possa ser compreendida na apresentação conflituosa do passado com o presente, e do presente com o futuro. Através das máscaras e das nuances linguísticas que ora transformarão o ator no herói e o coro no conjunto de cidadãos que o julga, ora farão identificar o ator com o cidadão e o coro com o herói antigo, a ambiguidade se imporá na relação entre aquilo que está distante e supostamente ausente e o que alcança o espectador e o implica desde um passado que se vê presentificado no visível da cena e no audível da palavra. Em outros termos, o aí e o agora que, tanto a máscara, quanto a linguagem de outrora instauram, não deixarão que o passado escape do presente e que o futuro torne-se não problemático no conflito tipicamente trágico do dáimon-êthos, da maldição-caráter.

Quando, mais tarde, a mola trágica se romper, será a relação conflituosa da nova espiritualidade da pólis com as lendas heróicas o que se perderá. $O$ fictício tomará conta do todo e o poeta trágico não precisará jogar com essa espécie de saber temporal constituído na re-apresentação do lendário. A tradição a que se vinculará o poeta será a do próprio teatro antigo, uma vez que a criação de peças trágicas pressuporá apenas a conformação às obras de seus grandes autores gregos, o que se preservará será uma tradição estética. 
Agora, se não há dúvida de que a tradição do teatro antigo nos legou algo de sua experiência, a ponto de nomearmos tragédias algumas obras de Shakespeare e Goethe e entendermos como trágicos também alguns momentos do cinema de Pasolini e Bergman, por exemplo, como é possível falar em morte da tragédia, em rompimento da mola trágica? Ao mesmo tempo, como é possível que um mundo sem deuses, com uma compreensão da ação que a concebe guiada por uma faculdade interior que nem existia para o grego do século $V$ a.c: a vontade, comporte ainda lugar para que, nele, algo se denomine tragédia?

A solução a essas perguntas depende da compreensão de história que orienta o pesquisador, pensador ou colecionador que as formula. A diferença ficará muito clara se tomarmos como opostos o conceito de transistoricidade característico da resposta de Vernant e Naquet a essas mesmas perguntas - e a noção de intransmissibilidade, indicada no uso das citações por Arendt. Enquanto ambos respondem ao fim que a tragédia encontrara já na Grécia Antiga, pois, na diferença dos tempos, questionam sobre a possibilidade de vir a conceder o nome "tragédia" a algo que hoje se apresenta, o trans de transistoricidade remete a um "para além da história" ou, no sentido que dão a ele Vernant e Naquet, a um "através da história", enquanto o trans de intransmissibilidade, por se encontrar precedido da preposição negadora in, impede tanto o "para além" como o "através", sugerindo que a experiência de algo que se chamou de tragédia não seja passível de transmissão, ou, para usarmos a famosa imagem evocada por Arendt, sugerindo que se algo nos foi legado, tal herança nos foi deixada sem nenhum testamento.

De um lado, portanto, tradição estética. Sobre a transistoricidade os helenistas franceses dizem mais ou menos o seguinte: é mesmo intrigante que a antiga arte grega possa, a despeito das transformações subjetivas e mundanas do homem moderno em relação ao cidadão ateniense do século $V$, continuar nos tocando. Tal fato é ainda mais intrigante por essas obras nos tocarem profundamente, aparecendo como ideias eternas quando confrontadas com as imensas transformações nos modos de produção material e social desde a antiguidade até os nossos dias. Se estas questões ilustram o paradoxo encontrado por Marx na Introdução Geral à Crítica da Economia Política, continuam os autores, a resposta de Marx é ali insuficiente. Em sua obra, há algo que supera a sua afirmação de que a arte grega nos toca por ser como a nossa infância. 
[...] há em Marx observações que deveriam nos permitir enfrentar com melhores armas esse problema do histórico e do transistórico na arte. Numa outra obra [Esboço de uma Crítica da Economia Política], Marx observa, de fato, que o homem é o único animal em quem os sentidos (a visão, a audição, o olfato etc.) não são apenas resultados da evolução biológica das espécies, mas produtos duma história social e cultural, especialmente duma história das diversas artes nas suas especificidades, cada qual atuando no seu domínio próprio; [...] Tudo o que Marx afirma das relações da mão e do trabalho, que a mão cria o trabalho, mas que o trabalho também cria a mão, sendo a mão, ao mesmo tempo, o órgão e o produto do trabalho, ele diz também da arte e de suas obras: [...] Em arte, a produção não produz apenas um "objeto para o sujeito", mas um "sujeito para o objeto" (Marx) esse objeto novo que acaba de ser criado (2005, p. 213-214) .

Já a consciência do mimético diria dessa constituição subjetiva. Esta aparece, em Vernant e Naquet, ao mesmo tempo, como a condição e o produto do teatro trágico. Se a tradição poética anterior não se sustentava na imitação, mas no desvelamento do real - pensam os dois helenistas -, a tomada de consciência do fictício inventará a possibilidade para que os acontecimentos dolorosos que a tragédia coloca em cena como ficção, na produção de um roteiro que os "depura simplificando, condensando, sistematizando", tornem "os sofrimentos humanos, comumente deplorados ou sofridos, objetos de uma compreensão" (2005, p. 218). É sob esse aspecto, então, que:

[...] o estatuto da tragédia grega parece comparável ao de uma ciência [...] ou de uma disciplina intelectual como a filosofia tal como instituída por Platão e Aristóteles ao fundarem suas escolas. [...] Ainda hoje filosofar supõe que nos integremos a essa tradição [...]. Do mesmo modo, se temos o direito de chamar tragédias às obras de Shakespeare, de Racine, ou algumas obras contemporâneas, é porque com os deslocamentos, com as mudanças de perspectiva ligadas ao contexto histórico, elas se enraízam na tradição do teatro antigo, onde encontraram, já traçado, o quadro humano e estético próprio do tipo de dramaturgia que instaurou a consciência trágica (2005, p. 214-215, grifos meus).

\footnotetext{
${ }^{4}$ Em Mito \& Política (2002), Vernant sustenta diversas vezes uma filiação não dogmática a Marx. Juntamente a Meyerson e Louis Gernet, o pensamento de Marx marca o percurso metodológico de suas pesquisas ao dar forma às interrogações de entrada no universo da Grécia Antiga ao helenista que, por sua vez, de lá retorna com questões que retroagem sobre sua leitura de Marx, complexificando-a em pelo menos dois níveis: o da relação entre o fato econômico e a religião; e o da relação entre economia e política. Em relação ao primeiro, lê-se: "Cheguei ao marxismo pelo ateísmo revolucionário. Logo, o problema da religião era para mim simplesmente uma questão de ideologia. Mas, uma vez mergulhado nela, quando me aprofundei nos mitos gregos, na religião grega, percebi que as relações entre religião e sociedade não são tão simples; no entanto olhei também um pouco melhor para a história do marxismo e para os próprios textos de Marx, e percebi que talvez a ideia que eu tinha deles era um pouco sumária". Em relação ao segundo: "O resultado para um marxista é que se colocavam questões [...]. Entre os gregos, como dizia Marx, há uma predominância do fator político que se deve explicar a partir de determinados motivos - dentre os quais os mais importantes são de ordem econômica. Mas a explicação de um marxista jamais passa diretamente do fato econômico ao fato intelectual, mas passa sempre pela mediação do político." (p.97)
}

R. Inter. Interdisc. INTERthesis, Florianópolis, v.12, n.1, p.321-336, Jan-Jun. 2015 
De outro lado, do lado arendtiano, encontraríamos a ausência de um tecido discursivo capaz de dar conta da continuidade suposta no "através da história". Não há tradição que nos tenha legado o tesouro perdido da tragédia. Se uma tradição estética do trágico como consciência do fictício de fato se constituiu, ela nos contaria mais do soterramento da experiência trágica do que de uma abertura para a sua compreensão, ao menos no que ela carrega de específico, de genuíno, ou seja, de seu vínculo originário com a política. Neste sentido, poderíamos ler o comentário de Arendt sobre o modo de 0 idealismo alemão acessar a Grécia antiga ${ }^{5}$ como um reconhecimento de que há sim uma tradição não apenas estética, mas filosófica que permite o encontro do homem moderno com a antiga arte grega, mas que essa tradição se constitui no ocaso do trágico diante do ser, uma vez que, na atemporalidade por ela suposta, concede ao pensamento uma qualidade que ele não tem de transcendência às aparências, enquanto confronta o pensamento temporal enraizado no mundo que a tragédia, soterrada pela instituição da filosofia, fracassou em instituir.

De fato, assemelhado a outros nomes, talvez algo do trágico nos tenha sido transmitido: a experiência do fictício, como frisam Vernant e Naquet. Mas sem o atravessamento dilemático da ambiguidade que faz questionar a cidade, a justiça e o cidadão, do sujeito que se constitui no espetáculo talvez possa ser dito que é o sujeito do lazer, ou ainda, de uma certa recepção da psicanálise, mas poderíamos nomeá-lo sujeito político? Os fracassos da responsabilidade denunciados por Arendt parecem dizer que não. Não há dilema atravessado no homem que se desculpa pelo assassinato em massa por ser um mero dente de engrenagem. No discurso de Eichmann, há, ao invés disso, esvaziamento do trágico, pois lhe falta o sofrimento típico da responsabilidade do herói: responder individualmente por uma força que, supostamente, agiu por trás de suas costas ${ }^{6}$.

\footnotetext{
${ }^{5}$ Ver a crítica de Arendt ao Idealismo Alemão (1995, p. 299-305).

${ }^{6}$ Se a própria ideia de engrenagem poderia corresponder, secularmente, àquela noção de destino que tensiona a mola trágica, e se a descrição de Eichmann feita por Arendt tem algo de trágico por separar a harmatía, o erro trágico, da intenção do agente - "o que me deixou aturdida foi que a conspícua superficialidade do agente tornava impossível rastrear o mal incontestável de seus atos, em suas raízes ou em seus motivos, em níveis mais profundos. Os atos eram monstruosos, mas o agente - ao menos aquele que estava em julgamento - era bastante comum, banal, e não demoníaco ou monstruoso" (2010, p.18) -, Agamben, em O que resta de Auschwitz (2008), pode deixar mais clara nossa afirmação: "Tal é o sentido do especial Befehlnotstand, do 'estado de constrição consequente a uma ordem' lembrado por Levi a propósito dos membros do Sonderkommando, que torna qualquer conflito trágico impossível em Auschwitz. O elemento objetivo
} 
Se há esvaziamento do trágico, Arendt não poderá remeter à tragédia sob o signo da continuidade. Em seu modo não desenvolvimentista de conceber a história, não há progresso ou decadência necessários, mas se a mundaneidade é condição humana, os acontecimentos do mundo desafiam a integridade de nosso espírito. Isso a autora nos conta pelas palavras de Montesquieu:

O homem, este ser flexível que, em sociedade, liga-se aos pensamentos e expressões de outros, é tão capaz de conhecer sua própria natureza, quando esta lhe é mostrada, quanto o é de perdê-la, a ponto de sequer chegar a senti-la quando a estão roubando. (MONTESQUIEU apud ARENDT, 2002, p. 47).

Não haveria, desta maneira, para a autora, uma espécie de subjetivação trágica garantida no "através da história". Nesse sentido, o esvaziamento do pensar denunciado por Arendt em diversos momentos de sua obra pode ser considerado signo do esgotamento da tensão que contrapõe à hybris um ethos, rompimento da mola constituinte da tragicidade inclusive em seu aspecto já secularizado.

Diante do esgotamento, contudo, há ainda a memória. Guardada, felizmente, não apenas em nosso espírito tão frágil que capaz de ser furtado em suas faculdades, mas nas palavras e na poesia.

Em Sobre a Revolução, depois de constatar o fracasso dos conselhos revolucionários em legar ao futuro a sua herança, Arendt diz o seguinte sobre a tarefa do poeta:

Nada há que possa compensar este fracasso ou obstar a que ele se torne definitivo, exceto a memória e a recordação. E, desde que o armazém da memória é mantido e cuidado pelos poetas, cuja função é encontrar e criar as palavras de que vivemos, pode ser prudente voltarmo-nos [a eles] (2001, p. 345).

É precisamente nessa volta que Arendt recorda as palavras de Édipo em Colono, confrontado-a com a resposta de Teseu - "era a polis, o espaço das ações livres e das palavras vivas dos homens, aquilo que poderia dotar a vida de esplendor" (2001c, p. 246).

Estamos diante da constatação do soterramento e da operação de desmontagem. A seleção arendtiana do que foi encoberto é, então, criteriosa: o que

que era, em todo caso, a instancia decisiva para o herói grego transforma-se, nesse caso, naquilo que impossibilita a decisão. $E$ por não conseguir mais dar conta de seus atos, a vítima procura refúgio [...] sob a nobre máscara da culpa inocente". (p.102). 
deverá ser resgatado do fundo do mar ou das profundezas do solo não é o típico, não é o que ao longo do tempo sugeriu a sucessão de "agoras" costurado na linha do que a cada dia se desenvolve mais um pouco, é o vínculo perdido com a política que precisará ser reencontrado no diálogo com o trágico, embora sempre como um objeto estranho ou como concessão de um nome antigo a algo que reaparece transfigurado no presente. Não será por acaso, portanto, que nos depararemos com Aristóteles e sua compreensão da tragédia como imitação da ação no momento em que Arendt denuncia, não como erro, mas como uma falácia ajustada ao caráter malogrado da ação, a tentativa filosófica de compreender o agir nos moldes da fabricação. Da mesma forma, o Hamlet que aparece em meio ao "Crise na Educação" (2001) relembra a responsabilidade política com o mundo e a descontinuidade passível de ser constituída com um novo capaz de recolocar, ainda que fragilmente, o mundo em seus gonzos.

Para concluir, é possível afirmar que, por um lado, o recurso arendtiano à citação não poderá ser compreendido se não indicar o intransmissível e a desmontagem, se não remeter aos momentos em que a autora nos fala sobre o que, na filosofia, soterrou os deuses: primeiramente, a eternidade do ser em confronto com a imortalidade divina, e sobre como, posteriormente, o ser soterrou aquele pensamento temporal e detido na aparência que se apresentara no espetáculo trágico, primeiro quando alçou encontrar na Grécia antiga o lugar de morada do ser, segundo quando, na crítica a tal empreitada, compreendeu a História nos moldes do que, apelidado de Processo, ainda era o mesmo, velho e conhecido ser da metafísica.

Por outro lado, ao indicar, ao mesmo tempo, o intransmissivel e o soterrado, a citação abre um campo em negativo onde a citabilidade do trágico já diz de uma tragicidade que não se esgota nos limites da tensão entre destino e liberdade, mas que se estende, alicerçada em metáforas teatrais evocativas das figuras do ator e do espectador, em direção à teorização do próprio pensar enraizado no tempo, conforme descrito em A Vida do Espírito (2010). Nesse contexto, as citações fariam pensar sobre o significado temporal de a poesia ser para Arendt, com suas metáforas, aquilo que unifica um mundo que aprendemos a separar em um mundo de aparências e um outro, o mundo do ser. Se na crítica arendtiana da metafísica o modelo de tempo adotado pelo filósofo sempre correspondeu à sua dedicação a 
tudo o que era eterno, e se essa região mostrou-se, desde o início, embaraçosamente silenciosa, já a fugacidade do sentido da palavra poética, em choque com a permanência de um sentido que a acompanha de forma duradoura quase que a despeito do tempo, parece colocar-nos naquele espaço em que é o encontro, no homem, do passado com o futuro o que constitui um pensar assentado no tempo e, em que, tragicamente, presente, passado e futuro estão no aí da cena, estão no aí do mundo.

Enraizado em um mundo de aparências, tal pensar não prescindiria das palavras. Elas, ademais, têm na autora um peso temporal de significar um significado que já não é mais, mas que, tendo já sido, ainda ecoa nos ouvidos dos que sabem escutá-lo. Assim o é com a palavra política. Na linguagem, diz Arendt, "o passado está contido de modo ineliminável, frustrando todas as tentativas de se libertar dele de uma vez por todas. A pólis grega continuará a existir na base de nossa existência política - isto é, no fundo do mar - enquanto usarmos a palavra 'política'" (2001, p.197). Assim é também com a poesia na sua relação com o tempo. Por não estar a palavra poética aprisionada na eternidade de um sentido sempre-omesmo, ela carrega já o tempo dentro de si. Não nos conduz ao fora do tempo, mas nos lança na lacuna entre o passado e o futuro. E, embora, como diz Arendt, o caminhar nessa lacuna "não possa ser herdado nem transmitido pela tradição, cada grande livro de pensamento deixa-o entrever e como que o decifra - como diz Heráclito a respeito do Oráculo de Delfos, (...) 'ele não diz nem oculta, ele insinua'” (2010, p. 233).

Se é assim, talvez seja mesmo pela insinuação que as citações possam nos conduzir à tragédia. Encontrar um trágico insinuado nos confrontos arendtianos entre um pensar temporal assentado na aparência e uma filosofia do atemporal que fez da antiguidade a morada do ser. 


\title{
ON QUOTATION OF THE TRAGIC. NOTES ON TRADITION AND INTRANSMISSIBILITY
}

\begin{abstract}
If there is no doubt that the tradition of the ancient theatre has transmitted to us something of its own experience, to the point that we name as tragedies some works from Shakespeare and Goethe and we take as tragic some moments of the Pasolini and Bergman movies as well, for example, how is it possible to talk about the death of the tragedy, about the rupture of the tragic impulse? At the same time, how is it possible that a world without gods, with an understanding of the action that conceives it leaded by an inner faculty that did not even existed in the $5^{\text {th }}$ century BC in Greece, the will, still has a place for something called tragedy? The solution to these questions depends on the history understanding that leads the researcher, thinker or collector who build them up. The difference is clear if we understand as opposite concepts transhistoricity - typical of the answer from Vernant and Naquet to these same questions - and intransmissibility, indicated by Hannah Arendt on the use of quotes.
\end{abstract}

Keywords: Tragedy. Intransmissibility. Transhistoricity. Hannah Arendt. VernantNaquet.

\section{DE LA CITA DE LO TRÁGICO. NOTAS SOBRE TRADICIÓN E INTRANSMISIBILIDAD}

\section{Resumen}

Si no hay duda de que la tradición del teatro antiguo nos ha legado alguna cosa de su experiencia, al punto de nombrarse tragedias algunas de las obras de Shakespeare y Goethe y entenderse como trágicos también algunos momentos de las películas de Pasolini y Bergman, ¿cómo es posible hablar de la muerte de la tragedia, de la ruptura del resorte trágico? Al mismo tiempo, ¿cómo es posible que un mundo sin dioses, con una comprensión de la acción que la concibe conducida por una facultad interior que no existía para los griegos del siglo V AC, la voluntad, permite que todavía haya lugar en él, para algo que se llame tragedia? La solución a esas preguntas depende de la comprensión de la historia que orienta al investigador, pensador o coleccionista que las formula. Esta diferencia quedará muy clara si consideramos como opuestos el concepto de transhistoricidad - característico de la respuesta de Vernant y Naquet a esas mismas preguntas - y la noción de intransmisibilidad, indicada en el uso de las citaciones por Hannah Arendt.

Palabras clave: Tragedia. Transhistoricidad. Intransmisibilidad. Hannah Arendt. Vernant-Naquet 


\section{REFERÊNCIAS}

AGAMBEN, G. "A vergonha, ou do sujeito". In: O que resta de Auschwitz. São Paulo: Boitempo, 2008.

ARENDT, H. Homens em Tempos Sombrios. SP: Companhia das Letras, 2001.

ARENDT, H. A Condição Humana. RJ: Forense Universitária, 2001a.

ARENDT, H. Entre o Passado e o Futuro. SP: Perspectiva, 2001b.

ARENDT, H. Sobre a Revolução. Lisboa: Relógio D’Água Editores, 2001c.

ARENDT, H. Filosofia e Política. In: A Dignidade da Política. RJ: R. Dumará, 2002.

ARENDT, H. A vida do Espírito. RJ: Civilização Brasileira, 2010.

SONTAG, S. "A morte da Tragédia”. In: Contra a Interpretação. RS: I\&PM, 1987.

VERNANT, J-P. Entre Mito \& Política. SP: Edusp, 2002.

VERNANT, J-P; NAQUET, P. Mito e Tragédia na Grécia Antiga. SP: Perspectiva, 2005.

\section{Ensaio:}

Submetido em 30.07.2014

Aceito em 31.03. 2015 